\title{
Analisis Kelayakan Finansial Penggantian Lini Manual Menjadi Lini Otomatis Produk Refrigerator Switch di PT. MM
}

\author{
Andira ${ }^{1}$, Astika Arisnawati ${ }^{1}$ \\ 1) Industrial Engineering Department, Faculty of Engineering, President University \\ Jl. Ki Hajar Dewantara \\ Kota Jababeka,Cikarang, Bekasi - Indonesia 17550 \\ Email: astika_arisnawati@yahoo.com, andira@president.ac.id
}

\begin{abstract}
ABSTRAK
Data sales result dari FY10 sampai FY15 menunjukkan terjadi kenaikan permintaan produksi switch D-1. Jika dibandingkan dengan data budget yang diperoleh dari mother company, ada selisih angka yang bisa menyebabkan masalah karena ada ketidaktepatan budget dengan actual demand. Pada akhirnya terjadi kekurangan kapasitas produksi di FY16 sebagai akibat dari kesalahan persiapan kapasitas. Hal ini mendorong PT.MMM untuk melakukan metode forecasting yang tepat. Untuk memproyeksikan angka penjualan di tahun mendatang, digunakan forecasting metode trend linier. Karena ada kekurangan kapasitas di FY16 dan diperkirakan akan ada kenaikan permintaan di tahun selanjutnya, PT.MMM mengatasinya dengan melakukan investasi auto line. Investasi auto line ini juga merupakan solusi dalam menghadapi kenaikan labor cost setiap tahunnya. Dengan mentransformasikan manual line menjadi auto line, jumlah operator bisa berkurang, yang pada awalnya membutuhkan 7 operator per line sekarang berubah menjadi 4 operator per line. Setelah membandingkan angka forecast dengan kapasitas produksi, PT.MMM memerlukan investasi auto line di FY17, FY22, dan FY31 sampai ketiga manual line sudah habis tergantikan dengan auto line. Berdasarkan hasil analisis, hanya investasi auto line 1 yang dianggap layak dengan nilai payback period $=3$ tahun, net present value $=\$ 249,372.88$, internal rate of return $=18.93 \%$, dan profitability index $=1.62$.
\end{abstract}

Kata kunci: Payback Period, Net Present Value, Internal Rate of Return, Profitability Index

\begin{abstract}
Sales data of FY10 to FY 15 shows increasing of switch D-1 demand. In fulfilling the demand, budget of production have been allocated by the head company. In fact, there is gap between the budget and cost required by production department. The condition cause the capacity lower than the demand. It happened to FY16. The problem should be solved because it has bad impact to customer satisfaction. Based on the problem identification, the problem of lack of budget can caused by the wrong estimation of demand. Refer to that problem, company decide to find out the better method in forecasting of demand and assume that the mother company will determine the suitable number of budget to produce as much as demand. Several methods of forecasting have been considered and trend liner method is the best method for the company demand pattern. Lack of capacity at FY16 before will require the increasing of capacity in several next periods. Changing the manual line to be automation line is an alternative to overcome the capacity problem. The result of analysis is automation line is more efficient than manual line. It reduced the number of operator from 7 to 4 per line. Adding one automation line need 3 years to get payback with net present value \$ $249,377.88$, internal rate of return is $18.93 \%$ and profitability is index 1.62
\end{abstract}

Keywords: Payback Period, Net Present Value, Internal Rate of Return, Profitability Index

\section{Pendahuluan}

Salah satu customer dari PT.MMM, yaitu produsen kulkas merk "T", terus meningkatkan penjualan kulkas. PT.T berinovasi menghadirkan kulkas terbaru beraneka motif. Mereka memperkenalkan kulkas terbaru dengan tiga varian tipe, yaitu tipe 1 di segmen kulkas satu pintu bermotif daun, tipe 2 bermotif batik, dan segmen kulkas dua pintu tipe 3 membawa motif serat kayu. Kulkas ini diyakini dapat meningkatkan penjualan, untuk memenuhi permintaan yang masih tinggi, produsen "T" menargetkan kapasitas produksi tipe ini mencapai satu juta unit per tahun. 
PT.MMM adalah salah satu perusahaan komponen elektronik refrigerator switch, baik untuk pasar lokal maupun pasar ekspor. Pertumbuhan industri kulkas berdampak pada peningkatan permintaan produksi refrigerator switch di PT.MMM. Pada fiscal year 2010, jumlah penjualan refrigerator switch mencapai 8 juta unit dan bertambah meningkat sampai 1 juta unit setiap tahunnya. Hingga pada fiscal year 2015, jumlah penjualan refrigerator switch mencapai hampir 14 juta unit per tahun.

Dengan adanya permintaan produksi yang cukup besar, salah satu masalah yang dihadapi PT.MMM adalah kapasitas lini produksi yang terbatas. Selama ini kapasitas yang digunakan adalah 3 line, maksimum beroperasi 3 shift atau 24 jam/hari, dengan 5 hari kerja setiap minggunya. Jika permintaan produksi melebihi kapasitas, maka kelebihan permintaan produksi akan dipenuhi dengan menambah jam kerja atau overtime di hari Sabtu dan Minggu. Tentu saja hal ini akan berdampak dengan penambahan direct labor cost untuk biaya overtime operator. Perlu diketahui bahwa labor cost setiap tahunnya terus meningkat, sedangkan customer tidak menginginkan kenaikan harga produk, malahan mereka lebih sering menginginkan cost down.

Di samping itu, ketiga line di PT.MMM sudah tua dan menambah beban tersendiri dalam proses produksinya. Mesin yang lama memerlukan biaya perawatan yang lebih tinggi dibandingkan mesin yang baru. Selain biaya perawatan rutin yang harus dikeluarkan, mesin yang relatif lebih tua lebih sering mengalami kerusakan dan juga memerlukan biaya yang tidak sedikit (Widiyanthi, 2007).

Seperti yang sudah diketahui bahwa labor cost tiap tahunnya semakin meningkat sekitar $10 \%$ per tahun, tetapi customer menginginkan low cost atas barang/jasa yang dibutuhkan. Sangatlah penting bagi perusahaan untuk bisa menyajikan harga yang kompetitif kepada customer dengan tidak mengesampingkan aspek lainnya yang sudah disebutkan di atas. Jika perusahaan tidak mampu bersaing, tidak menutup kemungkinan customer akan beralih menggunakan produk kompetitor.

Di zaman automation ini, PT.MMM mencoba men-transformasikan manual line menjadi auto line dari jenis switch D-1. Melalui transformasi ini diharapkan direct labor cost bisa berkurang karena menggunakan operator yang lebih sedikit dibandingkan dengan manual line.

\section{Metode}

Metode yang digunakan untuk menganalisis data adalah DMAIC, antara lain sebagai berikut (Pyzdek, 2001.) :

\subsection{Define}

Jika dilihat dari sales result, ditemukan adanya peningkatan permintaan produksi switch D-1, yang menyebabkan kapasitas manual line tidak mencukupi. Menggunakan metode forecasting, bahwa di fiscal year 2016 dan seterusnya akan mengalami kenaikan juga.

\subsection{Measure}

Pada tahap ini dilakukan perhitungan sampai kapan kapasitas manual line bisa memenuhi permintaan customer.

\subsection{Analyze}

Dalam penelitian ini didapatkan bahwa kapasitas manual line tidak akan bisa mencukupi customer demand jika dibandingkan dengan hasil perhitungan forecast.

\subsection{Improve}

Dalam penelitian ini improvement tersebut adalah investasi auto line.

\subsection{Control}

Pada tahap ini dilakukan penilaian keefektifan improvement yang sudah dilakukan. Atau dengan kata lain pada tahap ini dilakukan verifikasi dan validasi hasil improvement, apakah sudah sesuai dengan target yang diharapkan. 


\section{Hasil dan Pembahasan}

\subsection{Perhitungan Kapasitas Produksi Manual Line}

Pada Gambar 1 di bawah terlihat bahwa proses terlama terjadi pada Pos 4 yaitu Moving Plate Greasing 1 dan Moving Plate Inserting dengan waktu 5.52 detik dengan kata lain, cycle time pada line produk D-1 adalah 5.52 detik. Dengan kata lain untuk memproduksi 1 pcs produk switch D-1 dibutuhkan waktu selama 5.52 detik. Karena proses yang paling lama terdapat pada Pos 4, maka waktu proses di Pos 4 dijadikan dasar cycle time dari manual line switch D-1. Berikut ini adalah satuan waktu untuk manual line switch D-1.

- Cycle Time $\quad 5.52$ second

- 1 Hour = 3,600 second

- Working Hour = 8 hours

- Shift/day = 3 shift/day

- Working Day = 20 days (normal day)

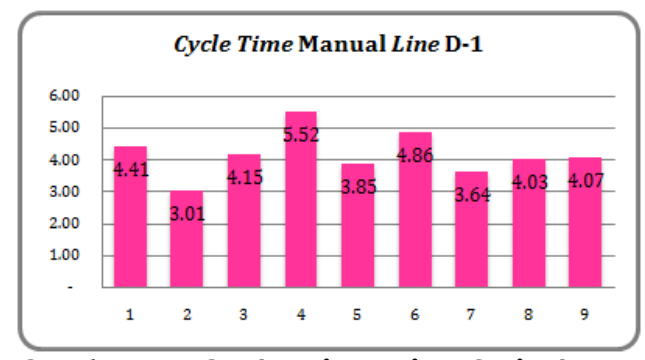

Gambar 1. Cycle Time Line Switch D-1

Line Operation Ratio (LOR) 100\%.

Diasumsikan tidak ada kendala saat proses mulai berjalan.

\begin{tabular}{|c|c|c|c|}
\hline Kapasitas per jam & $\begin{array}{l}=3,600 \\
=3,600 \\
=652 \cdot 17 \mathrm{pcs} \\
\approx 652 \mathrm{pcs}\end{array}$ & $\begin{array}{l}\text { CT } \\
5.52\end{array}$ & \\
\hline Kapasitas per shift & $\begin{array}{l}=\text { Kapasitas per jam } \\
=652 \mathrm{pcs} \\
=5,216 \mathrm{pcs}\end{array}$ & $\begin{array}{l}X \\
X\end{array}$ & $\begin{array}{l}\text { WH } \\
8\end{array}$ \\
\hline Kapasitas per day & $\begin{array}{l}=\text { Kapasitas per shift } \\
=5,216 \mathrm{pcs} \\
=15,648 \mathrm{pcs}\end{array}$ & $\begin{array}{l}x \\
x\end{array}$ & $\begin{array}{l}\text { Shift/day } \\
3\end{array}$ \\
\hline Kapasitas per bulan & $\begin{array}{l}=\text { Kapasitas per day } \\
=15,648 \text { pcs } \\
=312,960 \mathrm{pcs}\end{array}$ & $\begin{array}{l}x \\
x\end{array}$ & $\begin{array}{l}\text { WD } \\
20\end{array}$ \\
\hline
\end{tabular}

Line Operation Ratio (LOR) 90\%.

Diasumsikan terdapat kendala saat proses mulai berjalan. Kendala sebesar $10 \%$ yaitu terjadi downtime saat proses produksi, sebagai contoh adanya NG (not good) produk, change type, change tool.

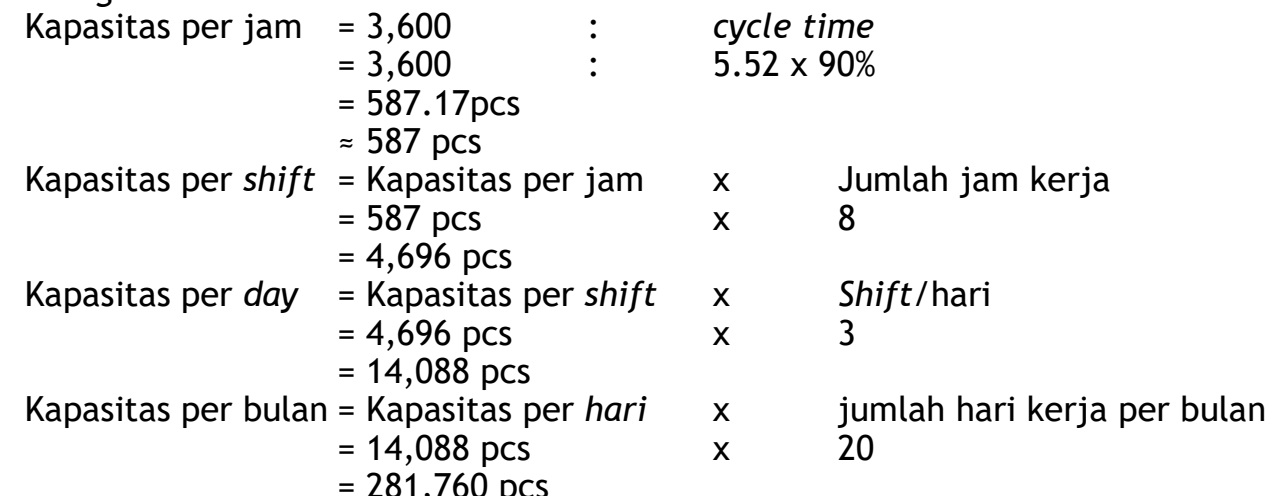


Jika melihat kondisi aktual di lapangan, masih ada downtime yang terjadi, maka dipakai perhitungan kapasitas dengan LOR $90 \%$. Berdasarkan perhitungan di atas didapatkan kapasitas produksi manual line switch D-1 adalah :

$\begin{array}{rlr}\text { Kapasitas per bulan } & =281,760 \mathrm{pCs} & \rightarrow 1 \mathrm{lini} \\ & =845,280 \mathrm{pCs} & \rightarrow 3 \mathrm{lini}\end{array}$

\subsection{Hasil Penjualan FY10-FY15}

Dalam 5 tahun terakhir, mulai fiscal year (FY) 2010 sampai fiscal year 2015, permintaan produksi switch D-1 semakin meningkat, dengan kapasitas produksi internal yang relatif konstan, maka perusahaan dituntut untuk mencari cara bagaimana memenuhi demand yang ada. Selama ini cara yang dilakukan adalah mengoptimalkan jam overtime di hari Sabtu dan Minggu. Dalam memperkirakan penjualan, perusahaan hanya menggunakan budget yang sudah ditentukan oleh mother company, dan tidak ada satu pun metode forecasting yang dilakukan.

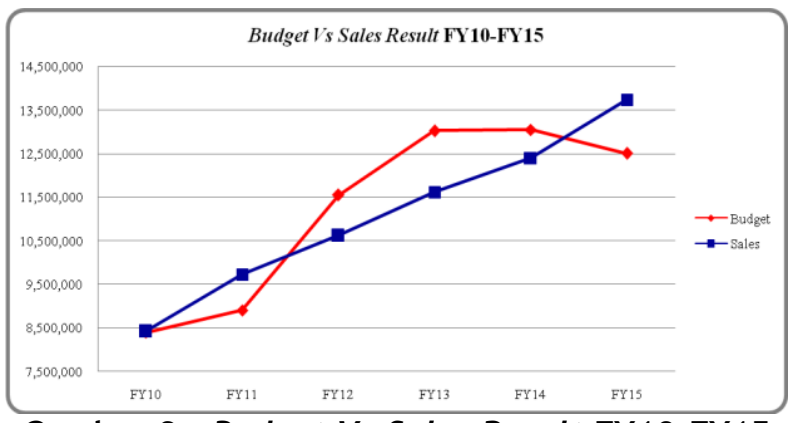

Gambar 2. Budget Vs Sales Result FY10-FY15

Dari Gambar 2 di atas dapat dilihat bahwa rasio kenaikan hasil penjualan mengalami kenaikan rata-rata sebesar $10.32 \%$ setiap tahunnya. Dari Gambar 2 di atas juga ditemukan bahwa masih ada selisih yang cukup besar antara budget dengan sales result. Hal ini menjadi masalah yang harus diselesaikan dan diperlukan metode forecasting yang tepat.

\subsection{Proyeksi Permintaan}

Dari analisis perkembangan industri kulkas di atas, diperkirakan akan ada kenaikan permintaan produksi refrigerator door switch di PT.MMM hingga beberapa tahun ke depan. Dengan demikian akan meningkatkan beban produksi di departemen switch production untuk bisa memenuhi demand tersebut. Jika dilihat Gambar di bawah ini, hasil penjualan switch D-1 dari FY10-FY15 mengikuti pola data trend.

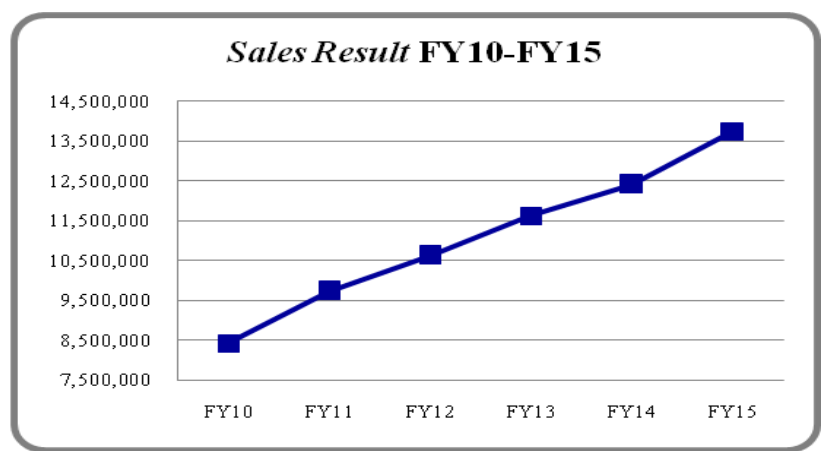

Gambar 3. Sales Result FY10-FY15

Jika melihat data di atas maka perlu dilakukan forecasting dengan metode peramalan yang paling tepat untuk perkiraan penjualan switch D-1 di beberapa tahun ke depan. Di bawah ini adalah metode peramalan dengan menggunakan pola trend linier. Prosedur perhitungannya adalah sebagai berikut (Husnan dan Suwarsono, 2000).:

a) Untuk data penjualan $\mathrm{dt}, \mathrm{t}=1,2,3, \ldots . \mathrm{N}$

b) Gunakan eliminasi dan substitusi untuk memperoleh parameter a dan b.

$Y \quad=a+b \cdot X$

$\Sigma Y=n \cdot a+b \cdot \Sigma X$ 
$\Sigma X Y$

$$
=a \cdot \Sigma X+b \cdot \Sigma X^{\wedge} 2
$$

\section{Cara eliminasi}

\begin{tabular}{|c|c|c|}
\hline $\begin{array}{l}66,521,757 \\
184,106,677\end{array}$ & $\begin{array}{l}=6 . \mathrm{a} \\
=15 . \mathrm{a}\end{array}$ & $\begin{array}{l}+ \text { b. } 15 \\
+ \text { b.55 }\end{array}$ \\
\hline $\begin{array}{l}166,304,393 \\
184,106,677\end{array}$ & $\begin{array}{l}=15 \cdot \mathrm{a} \\
=15 \cdot \mathrm{a}\end{array}$ & $\begin{array}{l}+37.5(b) \\
+b .55\end{array}$ \\
\hline $\begin{array}{l}-17,802,285 \\
b\end{array}$ & $\begin{array}{l}=0 \\
=1,017,273\end{array}$ & $+(-17.5) b$ \\
\hline $\begin{array}{l}\text { Cara substitusi } \\
66,521,757 \\
66,521,757 \\
66,521,757 \\
a\end{array}$ & $\begin{array}{l}=6 \cdot a \\
=6 \cdot a \\
=6 \cdot a \\
=8,543,776\end{array}$ & $\begin{array}{l}+ \text { b. } 15 \\
+1,017,273(15) \\
+15,259,101\end{array}$ \\
\hline
\end{tabular}

Dari hasil perhitungan nilai a dan $\mathrm{b}$ di atas, maka persamaan trend adalah sebagai berikut :

$\mathrm{Y}=8,543,776+1,017,273(\mathrm{X})$

Dengan demikian forecast penjualan untuk tahun 2016 adalah :

$$
\begin{array}{ll}
Y & =8,543,776+1,017,273(\mathrm{X}) \\
Y & =8,543,776+1,017,273(6) \\
Y & =8,543,776+6,103,640 \\
Y & =14,647,416
\end{array}
$$

\begin{tabular}{|c|c|c|c|c|c|}
\hline $\mathrm{n}$ & Tahun & Penjualan & $x$ & $x^{\wedge} 2$ & $x y$ \\
\hline 1 & FY10 & $8,419,900$ & 0 & 0 & $\rightarrow$ \\
\hline 2 & FY11 & $9,727,899$ & 1 & 1 & $9,727,899$ \\
\hline 3 & FY12 & $10,616,832$ & 2 & 4 & $21,233,664$ \\
\hline 4 & FY13 & $11,619,304$ & 3 & 9 & $34,857,912$ \\
\hline 5 & FY14 & $12,401,908$ & 4 & 16 & $49,607,632$ \\
\hline 6 & FY15 & $13,735,914$ & 5 & 25 & $68,679,570$ \\
\hline & & $66,521,757$ & 15 & 55 & $184,106,677$ \\
\hline
\end{tabular}

Tabel 2 Perhitungan Trend Garis Lurus

\begin{tabular}{|c|c|r|c|r|r|r|}
\hline $\mathbf{t}$ & $\begin{array}{c}\text { Fiscal } \\
\text { Year }\end{array}$ & $\begin{array}{c}\text { Permintaan } \\
(\mathbf{d t})\end{array}$ & $\mathbf{x}$ & $\mathbf{x}^{\wedge} \mathbf{2}$ & \multicolumn{1}{|c|}{$\mathbf{x y}$} & $\begin{array}{c}\text { Forecast(dt') Nilai Ft+m= at + bt } \\
(\mathbf{m})\end{array}$ \\
\hline 1 & FY10 & $8,419,900$ & 0 & 0 & - & $8,543,776$ \\
\hline 2 & FY11 & $9,727,899$ & 1 & 1 & $9,727,899$ & $9,561,049$ \\
\hline 3 & FY12 & $10,616,832$ & 2 & 4 & $21,233,664$ & $10,578,323$ \\
\hline 4 & FY13 & $11,619,304$ & 3 & 9 & $34,857,912$ & $11,595,596$ \\
\hline 5 & FY14 & $12,401,908$ & 4 & 16 & $49,607,632$ & $12,612,870$ \\
\hline 6 & FY15 & $13,735,914$ & 5 & 25 & $68,679,570$ & $13,630,143$ \\
\hline 7 & FY16 & & & & & $14,647,416$ \\
\hline 8 & FY17 & & & & & $15,664,690$ \\
\hline 9 & FY18 & & & & & $16,681,963$ \\
\hline 10 & FY19 & & & & & $17,699,237$ \\
\hline 11 & FY20 & & & & & \\
\hline
\end{tabular}

c) Langkah selanjutnya adalah melakukan verifikasi peramalan. Verifikasi peramalan digunakan untuk memeriksa apakah hasil peramalan sudah betul, yaitu menggunakan teknik moving range chart. Berikut ini adalah prosedur untuk melakukan uji verifikasi:

1) Hitung moving range untuk masing-masing periode.

$$
M R=\left|\left(d^{\prime}{ }_{t}-d_{t}\right)-\left(d^{\prime}{ }_{t-1}-d_{t-1}\right)\right|
$$

2) Hitung average moving range.

$$
\overline{M R}=\sum \frac{M R}{n-1}
$$

3) Hitung control limit. 
$U C L=+2.66(\overline{M R})$
$L C L=-2.66(\overline{M R})$

4) Hitung verification region.

Tabel 3. Uji Verifikasi

\begin{tabular}{|r|c|r|r|r|r|}
\hline $\mathbf{n}$ & Tahun & \multicolumn{1}{c|}{$\mathbf{d t}$} & \multicolumn{1}{c|}{$\mathbf{d t}^{\prime}$} & $\mathbf{e}=\mathbf{d t}-\mathbf{d t}^{\prime}$ & \multicolumn{1}{c|}{ MR } \\
\hline 1 & FY10 & $8,419,900$ & $8,543,776$ & $(123,876.00)$ & $290,725.60$ \\
\hline 2 & FY11 & $9,727,899$ & $9,561,049$ & $166,849.60$ & $128,340.40$ \\
\hline 3 & FY12 & $10,616,832$ & $10,578,323$ & $38,509.20$ & $14,801.40$ \\
\hline 4 & FY13 & $11,619,304$ & $11,595,596$ & $23,707.80$ & $234,669.40$ \\
\hline 5 & FY14 & $12,401,908$ & $12,612,870$ & $(210,961.60)$ & $316,732.60$ \\
\hline 6 & FY15 & $13,735,914$ & $13,630,143$ & $105,771.00$ & $197,053.88$ \\
\hline & & & & MR bar & \\
\hline
\end{tabular}

$\begin{array}{rlll}\mathrm{UCL} & =2.66 \times \mathrm{MR} \text { bar } & =2.66 \times 197,053.88 & =524,163.32 \\ \mathrm{LCL} & =-2.66 \times \mathrm{MR} \text { bar } & =-2.66 \times 197,053.88 & =-524.163 .32\end{array}$

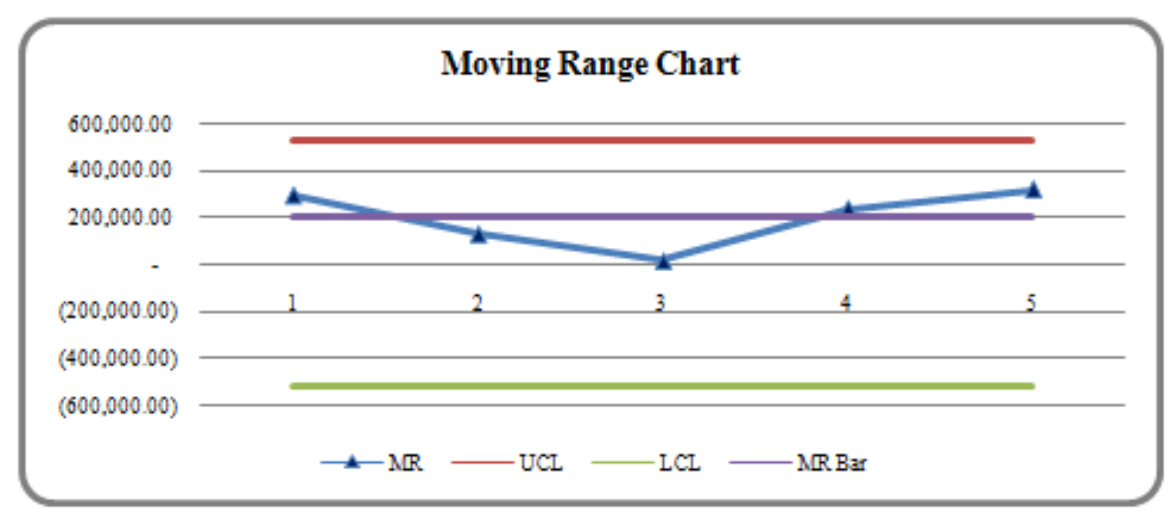

Gambar 4. Moving Range Chart

Dari Gambar 4 tidak ada data yang out of control, jadi forecasting bisa digunakan untuk perencanaan produksi. Tabel 4 berikut adalah data forecasting dari FY16 sampai FY40.

Tabel 4 Forecast dari FY16-FY40

\begin{tabular}{|c|r|}
\hline Fiscal Year & \multicolumn{1}{|c|}{ Forecast } \\
\hline FY16 & $14,647,416$ \\
\hline FY17 & $15,664,690$ \\
\hline FY18 & $16,681,963$ \\
\hline FY19 & $17,699,237$ \\
\hline FY20 & $18,716,510$ \\
\hline FY21 & $19,733,783$ \\
\hline FY22 & $20,751,057$ \\
\hline FY23 & $21,768,330$ \\
\hline FY24 & $22,785,604$ \\
\hline FY25 & $23,802,877$ \\
\hline FY26 & $24,820,150$ \\
\hline FY27 & $25,837,424$ \\
\hline FY28 & $26,854,697$ \\
\hline
\end{tabular}

\begin{tabular}{|c|r|}
\hline Fiscal Year & \multicolumn{1}{|c|}{ Forecast } \\
\hline FY29 & $27,871,971$ \\
\hline FY30 & $28,889,244$ \\
\hline FY31 & $29,906,517$ \\
\hline FY32 & $30,923,791$ \\
\hline FY33 & $31,941,064$ \\
\hline FY34 & $32,958,338$ \\
\hline FY35 & $33,975,611$ \\
\hline FY36 & $34,992,884$ \\
\hline FY37 & $36,010,158$ \\
\hline FY38 & $37,027,431$ \\
\hline FY39 & $38,044,705$ \\
\hline FY40 & $39,061,978$ \\
\hline
\end{tabular}

\subsection{Membandingkan Kapasitas Produksi dengan Forecast}

Dalam penelitian ini lebih ditekankan transformasi manual line menjadi auto line, tujuan utamanya adalah untuk mengurangi karyawan yang ada. Yang menjadi masalah adalah apakah investasi auto line itu layak dan kapan waktu yang tepat untuk melakukan investasi tersebut. Berikut ini adalah data kapasitas produksi manual line switch D-1 dengan sales result FY10-FY15. 
Tabel 5 Perbandingan Sales Result dan Kapasitas Manual Line

\begin{tabular}{|c|r|r|r|}
\hline FISCAL YEAR & SALES RESULT & $\begin{array}{c}\text { MANUAL LINE \#1,\#2,\#3, } \\
\text { 3 SHIFT }\end{array}$ & $\begin{array}{c}\text { OVERSTOCK / BACK } \\
\text { LOG }\end{array}$ \\
\hline FY10 & $8,419,900$ & $10,143,360$ & $1,723,460$ \\
\hline FY11 & $9,727,899$ & $10,143,360$ & 415,461 \\
\hline FY12 & $10,616,832$ & $10,143,360$ & $(1,473,472)$ \\
\hline FY13 & $11,619,304$ & $10,143,360$ & $(2,258,548)$ \\
\hline FY14 & $12,401,908$ & $10,143,360$ & $(3,592,554)$ \\
\hline FY15 & $13,735,914$ & $10,143,360$ & \\
\hline
\end{tabular}

Pada periode FY10 dan FY11, PT.MMM masih memiliki sisa kapasitas produksi, tetapi dimulai FY12 dan seterusnya sudah terjadi backlog atau kekurangan kapasitas. Selama ini untuk memenuhi kekurangan kapasitas tersebut, PT.MMM menerapkan sistem lembur (overtime) di hari Sabtu dan Minggu dengan kapasitas per hari ( 3 shift) :

1 line $=14,088$ pcs
3 line $=42,264$ pcs

Namun dimulai FY17 sampai seterusnya, PT.MMM tidak menerapkan sistem OT. Tabel 6 berikut ini adalah simulasi kapan harus dilakukan investasi auto line sampai ketiga manual line bisa habis tergantikan.

Tabel 6 Simulasi Waktu Penggantian Manual Line menjadi Auto Line

\begin{tabular}{|c|c|c|c|c|c|c|c|c|}
\hline $\begin{array}{c}\text { FISCAL } \\
\text { YEAR }\end{array}$ & $\begin{array}{c}\text { SALES } \\
\text { RESULT }\end{array}$ & BACK LOG & $\begin{array}{c}\text { MANUAL } \\
\text { LINE } \\
\# 1, \# 2, \# 3,3 \\
\text { SHIFT }\end{array}$ & $\begin{array}{c}\text { OVERSTOC } \\
\text { K / BACK } \\
\text { LOG }\end{array}$ & $\begin{array}{l}\text { OT, } 3 \text { LINE, } 3 \\
\text { SHIFT }\end{array}$ & $\begin{array}{c}\text { SABTU } \\
\text { (DAYS), MAX } \\
48\end{array}$ & $\begin{array}{c}\text { MINGGU } \\
\text { (DAYS), MAX } \\
48\end{array}$ & KURANG OT \\
\hline FY10 & $8,419,900$ & & $10,143,360$ & $1,723,460$ & & & & \\
\hline FY11 & $9,727,899$ & & $10,143,360$ & 415,461 & & & & \\
\hline FY12 & $10,616,832$ & & $10,143,360$ & $(473,472)$ & 507,168 & 12 & & \\
\hline FY13 & $11,619,304$ & & $10,143,360$ & $(1,475,944)$ & $1,479,240$ & 35 & & \\
\hline FY14 & $12,401,908$ & & $10,143,360$ & $(2,258,548)$ & $2,282,256$ & 48 & 6 & \\
\hline FY15 & $13,735,914$ & & $10,143,360$ & $(3,592,554)$ & $3,634,704$ & 48 & 38 & \\
\hline FY16 & $14,647,416$ & 446,712 & $10,143,360$ & $(4,504,056)$ & $4,522,248$ & 48 & 48 & 11 \\
\hline FY17 & $15,664,690$ & INVEST AUTO $\# 1$ & $19,111,680$ & $3,000,278$ & \multicolumn{4}{|c|}{2 MANUAL LINE $\# 1, \# 2,1$ AUTO LINE $\# 1$} \\
\hline FY18 & $16,681,963$ & & $19,111,680$ & $2,429,717$ & & & & \\
\hline FY19 & $17,699,237$ & & $19,111,680$ & $1,412,443$ & & & & \\
\hline FY20 & $18,716,510$ & & $19,111,680$ & 395,170 & & & & \\
\hline FY21 & $19,733,783$ & 622,103 & $19,111,680$ & $(622,103)$ & & & & \\
\hline FY22 & $20,751,057$ & INVEST AUTO $\# 2$ & $28,080,000$ & $6,706,840$ & \multicolumn{4}{|c|}{1 MANUAL LINE $\# 1,2$ AUTO LINE $\# 1, \# 2$} \\
\hline FY23 & $21,768,330$ & & $28,080,000$ & $6,311,670$ & & & & \\
\hline FY24 & $22,785,604$ & & $28,080,000$ & $5,294,396$ & & & & \\
\hline FY25 & $23,802,877$ & & $28,080,000$ & $4,277,123$ & & & & \\
\hline FY26 & $24,820,150$ & & $28,080,000$ & $3,259,850$ & & & & \\
\hline FY27 & $25,837,424$ & & $28,080,000$ & $2,242,576$ & & & & \\
\hline FY28 & $26,854,697$ & & $28,080,000$ & $1,225,303$ & & & & \\
\hline FY29 & $27,871,971$ & & $28,080,000$ & 208,029 & & & & \\
\hline FY30 & $28,889,244$ & 809,244 & $28,080,000$ & $(809,244)$ & & & & \\
\hline FY31 & $29,906,517$ & INVEST AUTO $\# 3$ & $37,048,320$ & $6,332,559$ & \multicolumn{4}{|c|}{3 AUTO LINE $\# 1, \# 2, \# 3$} \\
\hline FY32 & $30,923,791$ & & $37,048,320$ & $6,124,529$ & & & & \\
\hline FY33 & $31,941,064$ & & $37,048,320$ & $5,107,256$ & & & & \\
\hline FY34 & $32,958,338$ & & $37,048,320$ & $4,089,982$ & & & & \\
\hline FY35 & $33,975,611$ & & $37,048,320$ & $3,072,709$ & & & & \\
\hline FY36 & $34,992,884$ & & $37,048,320$ & $2,055,436$ & & & & \\
\hline FY37 & $36,010,158$ & & $37,048,320$ & $1,038,162$ & & & & \\
\hline FY38 & $37,027,431$ & & $37,048,320$ & 20,889 & & & & \\
\hline FY39 & $38,044,705$ & 996,385 & $37,048,320$ & $(996,385)$ & & & & \\
\hline FY40 & $39,061,978$ & INVEST AUTO $\# 4$ & $49,397,760$ & $9,339,397$ & \multicolumn{4}{|c|}{4 AUTO LINE \#1,\#2,\#3,\#4 } \\
\hline
\end{tabular}

\subsection{Spesifikasi Kapasitas Auto Line}

Untuk membuat auto line, PT.MMM sudah membuat standard cycle time yang bisa dibuat oleh departemen ME (Manufacturing Engineering) sebagai salah satu departemen di PT.MMM yang bertugas sebagai machine maker. Berikut ini adalah satuan waktu utnuk auto line switch D-1. 
JIE, Vol. 3, No.1, Maret 2018: 59-69

- Cycle Time = 1.51 second

- 1 Hour = 3,600 second

- Working Hour = 8 hours

- Shift/day = 3 shift $/$ day

- Working Day $\quad=20$ days (normal day)

Line Operation Ratio (LOR) $100 \%$.

Diasumsikan tidak ada kendala saat proses mulai berjalan.

Kapasitas per jam

$=3,600$

CT

$=3,600$

1.51

$=2,382.53 \mathrm{pcs}$

Kapasitas per shift

$\approx 2,382$ pCs

= Kapasitas per jam $\quad x \quad$ WH

$\begin{array}{lll}=2,382 \text { pcs } & x & 8\end{array}$

$=19,056 \mathrm{pcs}$

Kapasitas per day

$=$ Kapasitas per shift

$x \quad$ Shift/day

$=19,056 \mathrm{pCs}$

3

$=57,168$ pcs

Kapasitas per bulan

= Kapasitas per day $\quad \mathrm{X} \quad$ WD

$\begin{array}{lll}=57,168 \text { pcs } & x & 20\end{array}$

$=1,143,360$ pcs

Line Operation Ratio (LOR) 90\%.

Diasumsikan terdapat kendala saat proses mulai berjalan. Kendala sebesar $10 \%$ yaitu terjadi downtime saat proses produksi, sebagai contoh adanya NG (no good) produk, change type, change tool.

Kapasitas per jam

$=3,600$

CT

$=3,600$

$1.51 \times 90 \%$

$=2,144.28$ pcs

$\approx 2,144$ pcs

Kapasitas per shift

= Kapasitas per jam

$=2,144 \mathrm{pcs}$

WH

$=17,152 \mathrm{pcs}$

Kapasitas per day

$=$ Kapasitas per shift

$=17,152 \mathrm{pCs}$

$=51,456 \mathrm{pcs}$

Kapasitas per bulan

= Kapasitas per day

$=51,456$ pcs

$=1,029,120$ pcs

$\begin{array}{ll}\mathrm{X} & \mathrm{WH} \\ \mathrm{X} & 8\end{array}$

$x \quad$ Shift/day

$x \quad 3$

$x \quad$ WD

X 20

Jika melihat kondisi aktual di lapangan, masih ada downtime yang terjadi, maka dipakai perhitungan kapasitas dengan LOR $90 \%$. Berdasarkan perhitungan di atas didapatkan kapasitas produksi manual line switch D-1 adalah :

Kapasitas per bulan

Kapasitas per tahun

$$
=1,029,120 \text { pcs }
$$

$=12,349,440 \mathrm{pCs}$

$$
\rightarrow 1 \text { line }
$$

$\rightarrow 1$ line

\subsection{Analisis Keuangan}

Dari rencana investasi mesin auto line di PT.MMM, maka dilakukan perhitungan keseluruhan biaya, penghematan dan keuntungan yang didapat dari investasi tersebut. Metode yang digunakan untuk menghitung layak atau tidaknya proyek ini adalah sebagai berikut (Suliyanto, 2010). :

- Analisis Payback Period

- Analisis Net Present Value (NPV)

- Analisis Internal Rate of Return (IRR)

- Analisis Profitability Index (PI)

\subsection{Analisis Sensitifitas}

Analisis sensitivitas dilakukan dengan mengubah variable-variabel yang dianggap berpengaruh terhadap penilaian kelayakan, sehingga nantinya didapatkan variable mana yang paling sensitif terhadap penilaian kelayakan investasi terkait. Dalam penelitian ini digunakan tiga kategori, yaitu kategori optimis, kategori moderat, dan kategori pesimis (Afandi, 2009, Widiyanthi, 2007). 
1) Optimis

Pendapatan dianggap mengalami kenaikan sebesar $5 \%$, sedangkan biaya operasional dianggap tetap.

2) Moderat

Pendapatan dianggap tetap, sedangkan biaya operasional dianggap mengalami kenaikan sebesar $5 \%$.

3) Pesimis

Pendapatan dianggap mengalami penurunan 5\%, sedangkan biaya operasional dianggap mengalami kenaikan $5 \%$.

Hasil dari perhitungan analisis sensitivitas menggunakan ketiga metode skenario tersebut di atas, ditampilkan pada Tabel 7 sampai Tabel 9 di bawah ini :

Tabel 7 Perhitungan Analisis Sensitivitas Auto Line \#1

\begin{tabular}{|c|l|c|c|c|c|}
\hline \multirow{2}{*}{ No. } & \multicolumn{1}{|c|}{ Uraian } & \multirow{2}{*}{ Perhitungan Awal } & \multicolumn{3}{|c|}{ Sensitivitas } \\
\cline { 4 - 6 } & & & $\begin{array}{c}\text { Pend.Naik 5\%, } \\
\text { biaya tetap }\end{array}$ & $\begin{array}{c}\text { Pend.tetap, } \\
\text { biaya naik 5\% }\end{array}$ & $\begin{array}{c}\text { Pend.turun 5\%, } \\
\text { biaya naik 5\% }\end{array}$ \\
\hline 1 & Initial Investment & $\$ 400,853.00$ & $\$ 400,853.00$ & $\$ 400,853.00$ & $\$ 400,853.00$ \\
\hline 2 & Jangka Waktu & 7 tahun & 7 tahun & 7 tahun & 7 tahun \\
\hline 3 & Perhitungan & $12 \%$ & $12 \%$ & $12 \%$ & $12 \%$ \\
\hline 4 & Paybount Factor & 3 tahun 1 bulan & 3 tahun & 3 tahun 1 bulan & 3 tahun 3 bulan \\
\hline 5 & Net Present Value & $\$ 219,009.95$ & $\$ 249,372.88$ & $\$ 19,444.27$ & $\$ 189,081.34$ \\
\hline 6 & Initial Investment & $\$ 400,853.00$ & $\$ 400,853.00$ & $\$ 400,853.00$ & $\$ 400,853.00$ \\
\hline 7 & Profitability Index & 1.55 & 1.62 & 1.55 & 1.47 \\
\hline
\end{tabular}

Tabel 8 Perhitungan Analisis Sensitivitas Auto Line \#2

\begin{tabular}{|c|l|c|c|c|c|}
\hline \multirow{2}{*}{ No. } & \multicolumn{1}{|c|}{ Uraian } & \multirow{2}{*}{$\begin{array}{c}\text { Perhitungan } \\
\text { Awal }\end{array}$} & $\begin{array}{c}\text { Pend.Naik 5\%, } \\
\text { biaya tetap }\end{array}$ & $\begin{array}{c}\text { Pend.tetap, biaya } \\
\text { naik 5\% }\end{array}$ & $\begin{array}{c}\text { Pend.turun 5\%, } \\
\text { biaya naik 5\% }\end{array}$ \\
\cline { 4 - 6 } & & $\$ 706,439.96$ & $\$ 706,439.96$ & $\$ 706,439.96$ & $\$ 706,439.96$ \\
\hline 1 & Initial Investment & 7 tahun & 7 tahun & 7 tahun & 7 tahun \\
\hline 2 & $\begin{array}{l}\text { Jangka Waktu } \\
\text { Perhitungan }\end{array}$ & $12 \%$ & $12 \%$ & $12 \%$ & $12 \%$ \\
\hline 3 & Discount Factor & 4 tahun 8 bulan & 4 tahun 6 bulan & 4 tahun 8 bulan & 4 tahun 11 \\
bulan
\end{tabular}

Tabel 9 Perhitungan Analisis Sensitivitas Auto Line \#3

\begin{tabular}{|c|c|c|c|c|c|}
\hline \multirow[t]{2}{*}{ No } & \multirow[b]{2}{*}{ Uraian } & \multirow{2}{*}{$\begin{array}{c}\text { Perhitungan } \\
\text { Awal }\end{array}$} & \multicolumn{3}{|c|}{ Sensitivitas } \\
\hline & & & $\begin{array}{l}\text { Pend.Naik } 5 \% \text {, } \\
\text { biaya tetap }\end{array}$ & $\begin{array}{c}\text { Pend.tetap, biaya } \\
\text { naik } 5 \%\end{array}$ & $\begin{array}{c}\text { Pend.turun } 5 \% \text {, } \\
\text { biaya naik } 5 \%\end{array}$ \\
\hline 1 & Initial Investment & $\$ 1,959,013.63$ & $\$ 1,959,013.63$ & $\$ 1,959,013.63$ & $\$ 1,959,013.63$ \\
\hline 2 & $\begin{array}{l}\text { Jangka Waktu } \\
\text { Perhitungan }\end{array}$ & 7 tahun & 7 tahun & 7 tahun & 7 tahun \\
\hline 3 & Discount Factor & $12 \%$ & $12 \%$ & $12 \%$ & $12 \%$ \\
\hline 4 & Payback Period & $\begin{array}{c}\text { Lebih dari } 7 \\
\text { tahun }\end{array}$ & $\begin{array}{c}\text { Lebih dari } 7 \\
\text { tahun }\end{array}$ & Lebih dari 7 tahun & $\begin{array}{c}\text { Lebih dari } 7 \\
\text { tahun }\end{array}$ \\
\hline 5 & Net Present Value & $\$(874,324.29)$ & $\$(824,790.73)$ & $\$(870,580.79)$ & $\$(920,114.35)$ \\
\hline 6 & Initial Investment & $-1.60 \%$ & $-0.28 \%$ & $-1.50 \%$ & $-2.93 \%$ \\
\hline 7 & Profitability Index & 0.55 & 0.58 & 0.56 & 0.53 \\
\hline
\end{tabular}

Setelah melihat hasil perhitungan analisis sensitivitas, didapatkan keputusan dari masing-masing analisis investasi auto line \#1, \#2, \#3 menggunakan ketiga skenario tersebut di atas. Adapapun keputusannya dapat dilihat pada Tabel 10 sampai Tabel 12. 
Tabel 10 Keputusan Investasi Auto Line \#1

\begin{tabular}{|c|c|c|c|}
\hline Metode & Skenario & Hasil Perhitungan & $\begin{array}{c}\text { Keputusan } \\
\text { Investasi }\end{array}$ \\
\hline \multirow{3}{*}{$\begin{array}{c}\text { Payback } \\
\text { Period }\end{array}$} & $\mathrm{I}$ & 3 tahun & Layak \\
\hline & II & 3 tahun 1 bulan & Layak \\
\hline & III & 3 tahun 3 bulan & Layak \\
\hline \multirow{3}{*}{ NPV } & $\mathrm{I}$ & $\$ 249,372.88$ & Layak \\
\hline & II & $\$ 219,444.27$ & Layak \\
\hline & III & $\$ 189,081.34$ & Layak \\
\hline \multirow{3}{*}{ IRR } & I & $18.93 \%$ & Layak \\
\hline & II & $18.39 \%$ & Layak \\
\hline & III & $17.78 \%$ & Layak \\
\hline \multirow{3}{*}{$\mathrm{PI}$} & $\mathrm{I}$ & 1.62 & Layak \\
\hline & II & 1.55 & Layak \\
\hline & III & 1.47 & Layak \\
\hline
\end{tabular}

Tabel 11 Keputusan Investasi Auto Line \#2

\begin{tabular}{|c|c|c|c|}
\hline Metode & Skenario & Hasil Perhitungan & $\begin{array}{l}\text { Keputusan } \\
\text { Investasi }\end{array}$ \\
\hline \multirow{3}{*}{$\begin{array}{c}\text { Payback } \\
\text { Period }\end{array}$} & I & 4 tahun 6 bulan & Layak \\
\hline & II & 4 tahun 8 bulan & Layak \\
\hline & III & 4 tahun 11 bulan & Layak \\
\hline \multirow{3}{*}{ NPV } & I & $\$ 47,610.28$ & Layak \\
\hline & II & $\$ 4,146.98$ & Layak \\
\hline & III & $\$(20,399.64)$ & Tidak Layak \\
\hline \multirow{3}{*}{ IRR } & $\mathrm{I}$ & $13.12 \%$ & Layak \\
\hline & II & $12.35 \%$ & Layak \\
\hline & III & $11.48 \%$ & Tidak Layak \\
\hline \multirow{3}{*}{$\mathrm{PI}$} & I & 1.07 & Layak \\
\hline & II & 1.02 & Layak \\
\hline & III & 0.97 & Tidak Layak \\
\hline
\end{tabular}

Tabel 12 Keputusan Investasi Auto Line \#3

\begin{tabular}{|c|c|c|c|}
\hline Metode & Skenario & Hasil Perhitungan & $\begin{array}{l}\text { Keputusan } \\
\text { Investasi }\end{array}$ \\
\hline \multirow{3}{*}{$\begin{array}{l}\text { Payback } \\
\text { Period }\end{array}$} & I & Lebih dari 7 tahun & Tidak Layak \\
\hline & II & Lebih dari 7 tahun & Tidak Layak \\
\hline & III & Lebih dari 7 tahun & Tidak Layak \\
\hline \multirow{3}{*}{ NPV } & $\mathrm{I}$ & $\$ 824,790.73)$ & Tidak Layak \\
\hline & II & $\$(870,580.79)$ & Tidak Layak \\
\hline & III & $\$(920,114.35)$ & Tidak Layak \\
\hline \multirow{3}{*}{ IRR } & $\mathrm{I}$ & $-0.28 \%$ & Tidak Layak \\
\hline & II & $-1.50 \%$ & Tidak Layak \\
\hline & III & $-2.93 \%$ & Tidak Layak \\
\hline \multirow{3}{*}{$\mathrm{PI}$} & I & 0.58 & Tidak Layak \\
\hline & II & 0.56 & Tidak Layak \\
\hline & III & 0.53 & Tidak Layak \\
\hline
\end{tabular}

\section{Simpulan}

Simpulan yang dapat diambil dari analisis kelayakan investasi auto line \#1,\#2,\#3 di PT. MMM didaptkan hasil bahwa hanya investasi auto line \#1 auto line \#1 yang dianggap layak untuk untuk semua jenis metode perhitungan kelayakan investasi, dengan nilai payback period $=3$ tahun, net present value $=\$ 249,372.88$, internal rate of return $=18.93 \%$, dan profitability index $=1.62$.

Ditinjau dari aspek keuangan untuk rencana investasi auto line \#1 dan \#2 dianggap layak, maka PT.MMM harus segera melakukan investasi auto line \#1 di FY17 dan mempersiapkan investasi auto line \#2 di FY22. Untuk investasi auto line \#3 tersebut tidak layak untuk dilakukan oleh PT.MMM. 
Berdasarkan analisis aspek finansial, investasi auto line \#3 dianggap tidak layak, tetapi berdasarkan analisis forecasting akan ada kekurangan kapasitas, maka manajemen harus mencari cara lain untuk memenuhi customer demand dan ataukah tetap melakukan investasi auto line \#3 dengan mempertimbangkan bagaimana investasi itu bisa dianggap layak. Misalnya perusahaan bisa menaikkan harga sehingga profit yang didapat bisa lebih besar, ataukah mengurangi pengeluaran gaji operator dengan mengurangi jumlah operator yang ada di auto line switch D-1. Perlu dilakukan investasi auto line \#4 di FY40 karena berdasarkan perbandingan angka forecast dan kapasitas produksi, akan ada kekurangan kapasitas di FY39.

\section{Daftar Pustaka}

1. Afandi. (2009). Analisis Studi Kelayakan Investasi Pengembangan Usaha Distribusi PT. Aneka Andalan Karya. Jurnal Ekonomi, Vol. 1. No. 2, hal 11-13.

2. Husnan, S dan Suwarsono, M. (2000). Studi Kelayakan Proyek. Edisi ke-4. Yogyakarta: Unit Penerbit dan Percetakan.

3. Pyzdek, Thomas. (2001). The Six Sigma Handbook, McGraw-Hill Professional, New York .

4. Suliyanto. (2010). Studi Kelayakan Bisnis. Andi Offset, Yogyakarta

5. Widiyanthi, F. (2007). Analisis Kelayakan Investasi Penambahan Mesin Vacuum Frying Untuk Usaha Kecil Pengolahan Kacang Studi Kasus Di PD. Barokah Cikuing Majalengka Jawa Barat. Institut Pertanian Bogor : Bogor. Skripsi Manajemen Agribisnis. Vol. 2. No.3:24 - 27. 